\title{
3. 最近のテレビジョンの音響技術
}

若 栗 尚 ${ }^{\dagger}$ 小宮山 攝 ${ }^{\dagger}$

\section{1. まえ がき}

テレビの放送の初期には, 音声は 1 チャンネル（モ ノホニック)であった. 1969 年に音声多重放送が開始 され，2チャンネルの音声が送られるようになり，2 力国語音声放送，ステレオ音声放送が行われるように なった，現在では，直接衛星からの電波を受信する衛 星放送が行われるようになり, 音声もディジタル信号 を利用するようになって，その質は大幅に向上した。

最近, ハイビジョンの開発と共に, 画面の高精細 化, 広画角化によって, 映像の臨場感が増加した。こ のため, これに付加する音声も従来のステレオ方式よ りも映像とのバランスを考えた新しい方式とする必要 があり，3-1方式 4 チャンネル音声が開発された。

\section{2. ハイビジョン用ステレオ音声方式}

以下に，八イビジョン用 3-1 方式 4 チャンネルステ レオ音声を中心にその概略を解説する。

\subsection{3-1 方式 4 チャンネル音声再生}

八イビジョンの優れた映像に対する音声としては， 下記の点を中心に開発が行われた。

（a）従来よりも高い臨場感の得られる方式とし て, 独立音声のチャンネル $(\mathrm{CH})$ 数を 4 とす る.

（b）家庭内での複数の人や，ビデオシアタでの多 数の視聴のために, できる限り広い視聴位置で 映像と音像の方向のずれを少くするように，前 方中央に独立した音声再生のスピーカを置く, 前方 $3 \mathrm{CH}$ 方式を採用する。

（c）音に包まれる，サラウンド効果と後方の音源 の再生のために, 後方に独立した $1 \mathrm{CH}$ を用い る.ただし, 再生スピーカは複数個を割当て る.

\section{$\dagger$ NHK 放送技術研究所}

"Recent Audio Engineering for Television System" by Takashi Wakuri and Setsu Komiyama (NHK Science and Technical Research Laboratories, Tokyo) （d）映画の音声，特にドルビー方式などとの互換 性, $2 \mathrm{CH}$ ステレオ音声への変換の容易さを考 慮する。

これらは図 1 に示すような $2 \mathrm{CH}, 3 \mathrm{CH}$ と $4 \mathrm{CH}$ に よる 5 種類の計 7 種のスピーカ配置で行った再生音に 対する空間的印象, ステレオ効果の総合的判断, 映像 との融合感等についての心理的評価実験にもとづいて 決められた ${ }^{122)}$.

一般に複数個のスピーカによるステレオ音声の再生 は, システムに特有の最適聴取位置があり,これょり 外れた場所では劣化が起こる. $2 \mathrm{CH}$ ステレオでは, 左右両スピーカの中心軸上から外れた位置では虚音像 が側方のスピーカから聞こえるようになり, 多人数で の視聴では, この劣化が問題となる. $2 \mathrm{CH}$ ステレオ と，3-1 方式 $4 \mathrm{CH}$ ステレオとについて, 図2 に示す ような 50 インチ背面投射型八イビジョンディスプレ イを併用した実験で，それぞれの再生方式について， 中央位置 (最適聴取位置)に対して, 前後 1 座席, 左右 1,2 座席 ( 1 座席分 $75 \mathrm{~cm}$ の移動) ずれた位置での映 像, 音像の相乗的な効果も含めた総合的な品質の評価 を行った。

結果は, 図 2 の中に, $2 \mathrm{CH}$ の場合の中央での評価 值を 100 として相対的な值で示した。それぞれの配 置, 再生方式で, 左右対称の值となるため, それぞれ 片側のみについて表示してある. 3-1 方式 $4 \mathrm{CH}$ ステ レオの評価值も $2 \mathrm{CH}$ の中央の值の 100 を基準として 表してある。これから，3-1 方式 $4 \mathrm{CH}$ ステレオの多 人数聴取の場合の優れた点が明らかに読み取れ $3^{112)}$.

また，3-1 方式 $4 \mathrm{CH}$ ステレオで制作したプログラ ムを(1)式により $2 \mathrm{CH}$ ステレオ信号に変換したもの と, もともと $2 \mathrm{CH}$ ステレオ用に制作したものと品質 の比較を心理実験で行った結果は, 前者が後者に比べ て 7 段階評価で $0 \sim 0.5$ ランクの劣化しか生じないこ とが明らかになっだ'1). 

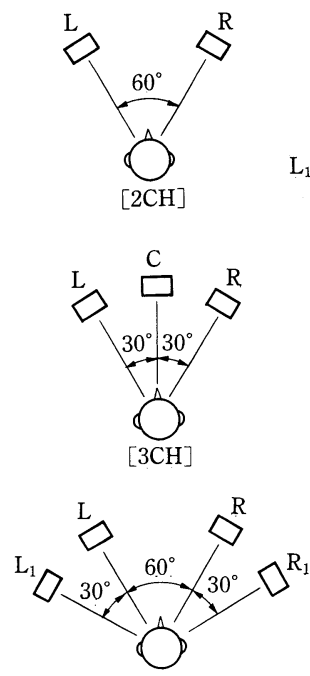

$[4-0(\mathrm{~A})]$

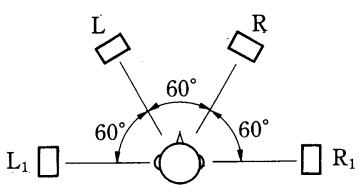

$[4-0(b)]$

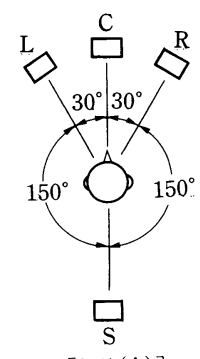

$[3-1(\mathrm{~A})]$

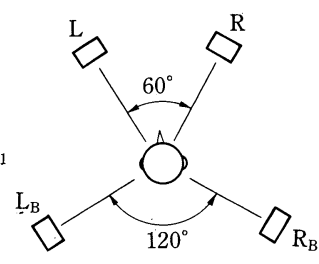

[2-2]

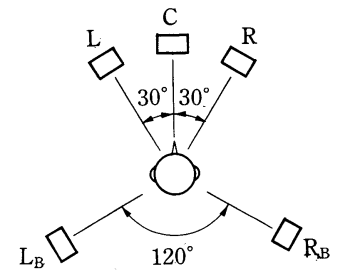

$[3-1(\mathrm{~B})]$

図 1 心理的評価実験に用いた $2 \mathrm{CH}, 3 \mathrm{CH}, 4 \mathrm{CH}$ ステレオのスピーカ配置

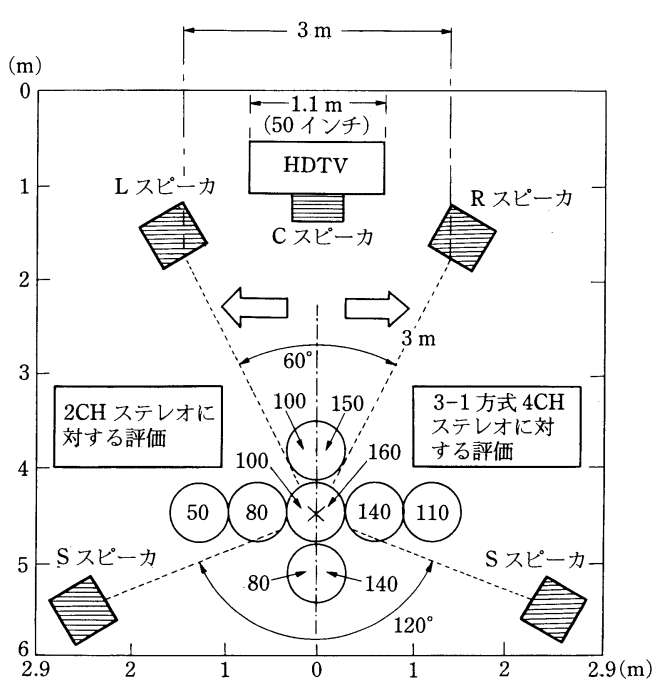

図 2 2 $\mathrm{CH}$ ステレオと 3-1 方式 $4 \mathrm{CH}$ ステレオのス ピーカ配置と, 映像との組み合せも含めた総合 品質評価の比較 $(2 \mathrm{CH}$ ステレオを中央の位置 で聴取した時の評価値を 100 として横方向に $75 \mathrm{~cm}, 150 \mathrm{~cm}$, 前後に $75 \mathrm{~cm}$ ずれた位置での 評価值（比例尺度）

$$
\left.\begin{array}{l}
L^{\prime}=L+0.7 C+0.7 S \\
R^{\prime}=R+0.7 C+0.7 S
\end{array}\right\}
$$

ただし， $L$ : 左チャンネル信号

$R:$ 右チャンネル信号

$C:$ 中央チャンネル信号

$S:$ 後方チャンネル信号
表 1 スタジオ内音声信号基本伝送規格

\begin{tabular}{c|c}
\hline \hline \multicolumn{1}{c|}{ 項 } & 目 \\
\hline 音声信号帯域 & $20 \mathrm{kHz}$ \\
標本化周波数 & $48 \mathrm{kHz}$ \\
量子化ビット数 & 16 \\
標本化時刻 & ステレオ時同一 \\
チャンネル数 & $1 \sim 4$ \\
符号化形式 & 2 の補数 \\
\hline
\end{tabular}

\section{2 ハイビジョン音声信号の符号化と伝送方式 ${ }^{9)}$}

ハイビジョン用音声のスタジオ内基本伝送規格は, 表 1 に示すものが提案されている.

八イビジョンの映像信号の帯域幅は $20 \mathrm{MHz}$ を超 えるが, 衛星等での伝送のため, MUSE 方式と呼ば れる帯域圧縮方式で約 $8 \mathrm{MHz}$ に圧縮している.しか し，音声信号のために，現行の衛星テレビ放送のよう な副搬送波を用いることはできないので, 垂直帰線期 間内にディジタル音声信号をベースバンドで時分割多 重する方式を採用している.

（1）音声信号のビットレートと圧縮 音声信号のビットレートは,

(a) 低 $C / N$ 時でも誤り率の少いこと

(b) MUSEのマスタークロック $16.2 \mathrm{MHz}$ と 簡単な関係になること

（c）国際的に用いられる $32 \mathrm{kHz}, 48 \mathrm{kHz}$ のサ ンプリング周波数と簡単な関係になること などを考慮して， $1.35 \mathrm{Mb} / \mathrm{s}$ が選ばれたが，これは現 


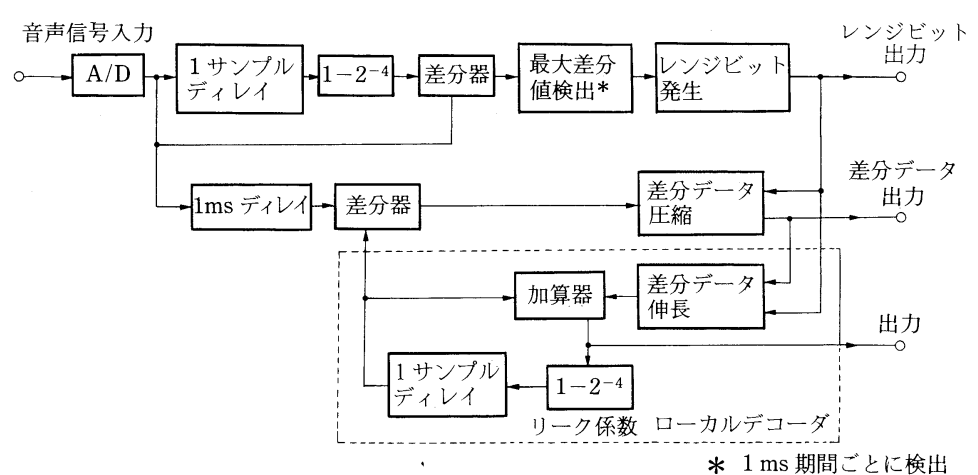

(a) エソコーダ

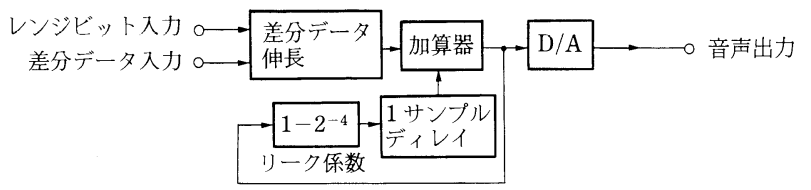

(b) デコーダ

図 3 準瞬時圧伸差分 PCM の構成

行衛星テレビ放送の伝送ビットレート $2.048 \mathrm{Mb} / \mathrm{s}$ の 約 $65 \%$ であり，帯域幅の圧縮が必要になる。ささに， $4 \mathrm{CH}$ の伝送を考えると 1 サンプル当たりは 8 ビット 程度の圧縮になる。このため, 音声信号のサンプル間 の相関を考慮に入れて, 連続するサンプル間の差分を 伝送する差分 $\mathrm{PCM}^{4)}$ と，この差分に準瞬時圧伸を適 用する方法を組み合せた準瞬時圧伸差分 PCM (DPCM Audio Near-instantaneous Compressing and Expanding: DANCE)を開発した ${ }^{4) 5)}$. この方式 により, $32 \mathrm{kHz}$ サンプリング，15ビット直線量子化 信号を 8 ビットに圧縮し， $4 \mathrm{CH}$ 多重伝送する $\mathrm{A}$ モー ドと, $48 \mathrm{kHz} 16$ ビット直線量子化信号を 11 ビット に圧縮, $2 \mathrm{CH}$ 伝送する B モードの 2 種の伝送モード を実現した。

(2) 準瞬時圧伸差分 PCM $(\mathrm{DANCE})^{4) 5)}$

図 3 に準瞬時圧伸差分 PCM の構成を示す。一般に 差分信号は，周波数の高い信号の場合ほど，同一振幅 入力信号に対しての値が大きくなる.このため, 差分 が 8 ビットを超える場合には，入力信号を $1 \mathrm{~ms}$ 毎の 区間に分け，最大差分を検出し，圧縮して伝送する．

この構成は，受信機側デコーダと同一構成の回路を エンコーダ側の一部に使用しており, 受信側でのデコ ードされた值を基に差分を作ることに相当し，誤差の 補正が常に行われることになる。

(3) リーク係数

差分 PCM は, 受信側では送られた差分值の累積加
算でデコードする方式であり，伝送路に生じた誤りは 訂正不能の時には, 誤差となり, 以後, 加算器内に残 ることになる。これを除くには, デコーダ側の加算出 力に $1-2^{-n}$ の係数を掛けて出力を減少させるリーキ ングと呼ばれる動作で誤差の収束を図る方法がある. この係数をリーク係数といい, 八イパスフィルタの 遮断特性を決めることになる。したがって，送り側 ではこの逆補正を行う。係数は, 聴感試験の結果とプ ログラム入力時の最多使用レンジとから $1-2^{-4}$ と決 めた ${ }^{6)}$.

（4）八イビジョン音声伝送方式の基本諸元

前述のように, 音声の伝送には $\mathrm{A}, \mathrm{B}$ の 2 つ モ ードが選択できるようになっている。

表 2 にハイビジョン音声伝送方式の基本諸元を示 す。また，A，B両モードのフレーム構成を図4 に示 す. 1フレームは 1350 ビットで構成され, 伝送ビッ トレートは $1.35 \mathrm{Mb} / \mathrm{s}$ となる.インタリーブは, 単 純な 16 サンプルのワードインタリーブの次に, ビッ トインタリーブを行う. 誤り訂正符号 $\operatorname{BCH}(82,74)$ は 84 ビット中の 1 ビットの誤り訂正と 2 ビットの誤 り検出を行うもので, バースト誤りに対応するため 16 個から成る $\mathrm{BCH}(82,74)$ のブロックをメモリーの 行方向に書込み, 16 行 $\times 32$ 列のマトリックスとし, これを左側の列から順に読出し送出する. 受信側で は, メモリー上に左側の列方向から書込み, 行方向に 読出しながら誤り訂正を行う。これで最大 16 ビット 
表 2 ハイビジョン音声伝送方式の基本諸元

\begin{tabular}{|c|c|c|c|c|}
\hline \multicolumn{3}{|r|}{ 伝送モード } & A & B \\
\hline \multirow{5}{*}{$\begin{array}{l}\text { 符 } \\
\text { 号 } \\
\text { 华 } \\
\text { 方 } \\
\text { 式 }\end{array}$} & \multicolumn{2}{|c|}{ 音声信号帯域幅 } & $15 \mathrm{kHz}$ & $20 \mathrm{kHz}$ \\
\hline & \multicolumn{2}{|c|}{ 標本化周波数 } & $32 \mathrm{kHz}$ & $48 \mathrm{kHz}$ \\
\hline & \multicolumn{2}{|c|}{ 標本化時刻 } & \multicolumn{2}{|c|}{ ステレオの場合同一 } \\
\hline & \multicolumn{2}{|c|}{ 音声量子化・圧伸 } & $\begin{array}{l}15 / 8 \text { ビット } \\
\text { 準瞬時圧伸 } \\
(8 \text { レンジ)*1 }\end{array}$ & $\begin{array}{l}\text { 16/11 ビット } \\
\text { 準瞬時圧伸 } \\
(6 \text { レンジ })^{* 2}\end{array}$ \\
\hline & \multicolumn{2}{|c|}{ リーク係数 } & \multicolumn{2}{|l|}{$1-2^{-4}$} \\
\hline \multirow{3}{*}{$\begin{array}{l}\text { 信 } \\
\text { 号 } \\
\text { 多 }\end{array}$} & \multicolumn{2}{|c|}{ 符号伝送速度 } & \multicolumn{2}{|l|}{$1350 \mathrm{~kb} / \mathrm{s}$} \\
\hline & \multicolumn{2}{|c|}{ 音声チャンネル数 } & 4 チャンネル & 2 チャンネル \\
\hline & \multicolumn{2}{|c|}{ 独立データ伝送容量 } & $128 \mathrm{~kb} / \mathrm{s}$ & $112 \mathrm{~kb} / \mathrm{s}$ \\
\hline $\begin{array}{l}\text { 多 } \\
\text { 重 }\end{array}$ & \multicolumn{2}{|c|}{ フレームビット数 } & \multicolumn{2}{|l|}{1350 ビット } \\
\hline $\begin{array}{l}\text { 方 } \\
\text { 式 }\end{array}$ & \multicolumn{2}{|c|}{ フレーム同期パターン } & \multicolumn{2}{|c|}{$\begin{array}{l}16 \text { ビット/フレーム } \\
(0001001101011110)\end{array}$} \\
\hline & \multicolumn{2}{|c|}{ 制御符号 } & \multicolumn{2}{|c|}{22 ビット/フレーム } \\
\hline & \multicolumn{2}{|c|}{ ビットインタリーブ } & \multicolumn{2}{|l|}{16 ビット } \\
\hline & \multirow{3}{*}{$\begin{array}{l}\text { 詋 } \\
\text { 知 } \\
\text { 御 }\end{array}$} & 音声・データ & \multicolumn{2}{|c|}{$\begin{array}{l}\mathrm{BCH} \cdot \mathrm{SEC} \cdot \mathrm{DED} \\
(82,74)\end{array}$} \\
\hline & & レンジビット & \multicolumn{2}{|c|}{$\begin{array}{l}\text { 上記に加えて } \mathrm{BCH} \text { - } \\
\mathrm{SEC} \cdot \mathrm{DED}(7,3)\end{array}$} \\
\hline & & 制御符号 & \multicolumn{2}{|c|}{$\begin{array}{l}\text { 繰り返し送出による } \\
\text { 多数決判定 }\end{array}$} \\
\hline 時 & \multicolumn{2}{|c|}{ 伝送区間 } & \multicolumn{2}{|l|}{ 垂直帰線区間 } \\
\hline 割 & \multicolumn{2}{|c|}{ 変調符号方式 } & \multicolumn{2}{|l|}{3 值信号 } \\
\hline 式 & \multicolumn{2}{|c|}{ 符号伝送速度 } & \multicolumn{2}{|l|}{ 12.15 Mbaud } \\
\hline
\end{tabular}

*1 15 ビット/サンプル一様量子化の差分を 8 ビット/サンプルに圧縮し て 32 サンプル毎に 8 レンジの圧伸制御情報を送る圧伸差分方式.

*2 16 ビット/サンプル一樣量子化の差分を 11 ビット/サンプルに圧縮 して 48 サンプル毎に 6 レンジの圧伸制御情報を送る圧伸差分方式.

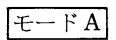

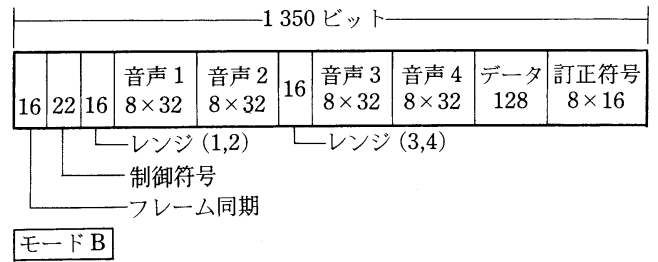

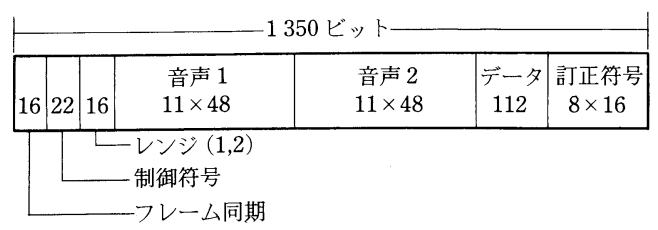

図 4 音声フレーム構成
までのバースト誤りに対して訂正が有効になる.

（5）誤り制御方式

レンジビットに対して $\mathrm{BCH} \cdot \operatorname{SEC} \cdot \operatorname{DED}(7 ， 3)$ の 1 詋り訂正， 2 誤り検出を行っている.さらに，この訂 正符号付きレンジビットに音声デー夕, 独立データと いっしょに $\mathrm{BCH} ・ \mathrm{SEC} \cdot \operatorname{DED}(82 ， 74)$ の訂正符号をつ けている.ブロック長 82 , 情報ビット長 74 , 検査ビ ット 8 の符号で, 82 ビット中 1 ビット誤り訂正, 2 ビット誤り検出ができる。この符号の生成多項式は $x^{8}+x^{7}+x^{4}+x^{3}+x+1$ で, レンジビットの方の生成 多項式は $x^{4}+x^{3}+x^{2}+1$ が用いられる.

(6) 品質評価

伝送された $\mathrm{A}$ モード (8ビット)の音質は 14.5 ビッ 卜一様量子化と同等で，Bモードは現行衛星テレビ放 送 $\mathrm{B}$ モードと等価であった ${ }^{7 / 8)}$.

\section{3． 映像と音声の関係}

テレビの映像と音声の相互関係には 2 つの要素があ る.ひとつは両者の時間的な同期の問題であり，もう ひとつは映像とステレオ音響の相乗効果の問題であ る。これらの問題はテレビ番組制作の高度化や音声の 多チャンネル化に伴い, 近年クローズアップされてき た問題である。

\section{1 映像と音声の時間的な同期}

10 年ほど前からテレビの音声の制作にポストプロ ダクションの手法が用いられるケースが増えてきてい る。これは映像を先に編集し，音声はあとで映像に合 わせてミキシングし，映像と同期をとりながらダビン グする手法である。これによって，映像に合わせた緻 密なミキシングが可能になる，そこで，ここでは，こ のポストプロダクションシステムで重要な働きをする VTR とテープレコーダのシンクロナイザの技術を紹 介する。

シンクロナイザは，録音時にVTR とテープレコー ダの双方に録音された SMPTE タイムコードを読取 って，両者の時間差がゼロになるようにテープレコー ダの走行を制御する働きをする装置である。このとき テープレコーダがアナログか PCM かで制御方法が違 ってくる. 図 5 にテープレコーダーがアナログの場合 のシステムの系統図を, 図6に PCM の場合の系統図 を示す。

テープレコーダがアナログの場合にはシンクロナイ ザはタイムコードを一致させた後も，ビデオの sync 信号とテープレコーダのタイムコードの位相がロック するようにテープレコーダの制御を行うのが普通であ る。したがって, VTRのタイムコードはビデオ信号 


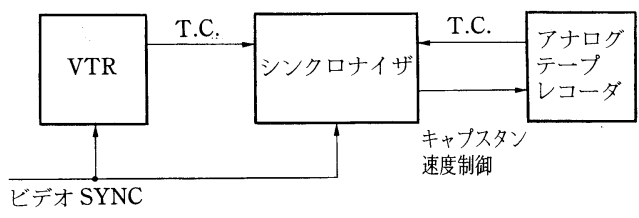

図 5 アナログテープレコーダとVTR の同期運転

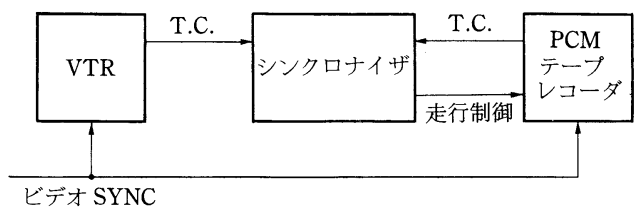

図 6 PCM テープレコーダとVTRの同期運転

と同期をとって記録されていなければならない。タイ ムコードが正常に記録されていれば $100 \mu \mathrm{s}$ 程度の同 期精度が得られるのが一般的である。

一方，PCM テープレコーダはアナログ方式と違っ て，サンプリング周期という絶対的な速度基準を持っ ているため, 走行速度の微調とは本来相いれない装置 である。したがって，シンクロナイザは夕イムコード を一致させたあとはテープレコーダの制御は行わず， PCM レコーダ自身が持っているビデオ信号との同期 走行機能に制御を明け渡すことが多かった。したがっ て, 完全な同期をとるためには録音時に PCM レコー ダをビデオ信号にロックさせておく必要があるなど, 操作性の面で煩雑であった。しかしながら，最近では タイムコードの時間差が常にゼロになるように PCM レコーダのワードシンクの周波数そのものを制御する 機種も見られるようになってきている.

さて, VTR 側のタイムコードは映像編集時に不連 続になるので, 多くの場合, 後でつけ替えられてしま う.したがって，テープレコーダの同期のためには編 集点ごとにテープレコーダ側のタイムコードとのオフ セットを見つける必要がある。オフセットを目と耳で 探す作業はオペレータの負荷が大きいので，VTRの 音声とテープレコーダの音声の相互相関関数から自動 的にオフセットを求める装置も実用化されている ${ }^{10)}$.

映像と音声の同期の問題は今のところ記録系が中心 であるが，画像フレームメモリーの一般化や，異なる フィールド周波数のテレビの方式変換が増えるにつれ 今後重要な技術になってこよう。

\section{2 映像と音像の空間的な一致 ${ }^{1112)}$}

テレビの大型化やハイビジョンの登場で，ステレオ 音響効果も映像とのバランスに注意を払う必要が出て きているが，このうち映像と音像の定位のずれについ

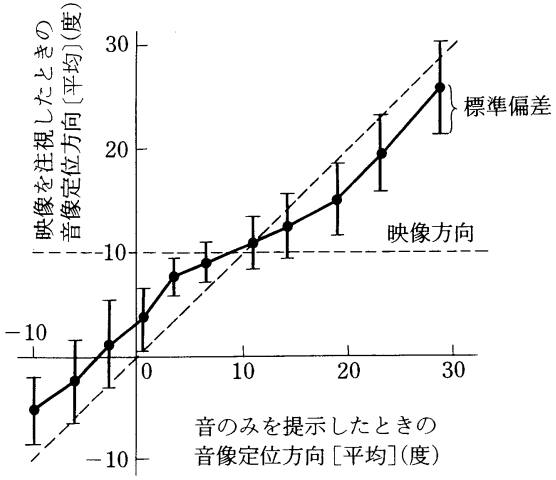

図 7 映像を注視することによる音像方向の変化

ては心理学的な研究が進んでいる

従来のテレビで映像と音像の定位のずれが気になら なかったのは, “ずれがある範囲内ならば音像が映像 の方向に引き付けられる”という視聴覚の性質によ る。その性質を明らかにした実験の一例を図 7 に示 す。これは 72 インチの投射型スクリーンに人物の映像 を映した場合と音だけで聞かせた場合とで，音が聞こ える方向がどの程度違うかを調べたものである．横軸 は映像を提示しないときの音像方向の平均值, 縦軸は 映像を提示したときの音像方向の平均値である．視覚 と聴覚が無関係であるとすればグラフは傾き $45^{\circ}$ の直 線になるはずであるが，実際は映像の方向に引き寄せ られているのがわかる。しかし，ずれが大きくなると 方向の違いは明らかに知覚できているのがわかる.

このような映像と音声の “空間的なずれ” は時間的 なずれと違って，さほど重要視されてこなかったが， テレビの大型化やハイビジョンの出現で重要な問題に なりつつある，そのため，映像と音像のずれに対する 主観評価も行われている.

図 8(a) と (b) はそれぞれ音響技術者と一般の人の 評価結果である。これは映像 (人物像) と音像の水平方 向のずれを 5 段階で評価し，その結果を系列範畴法で 尺度化して評価の平均値と標準偏差を求めたものであ る．ここでの評価 B と C のまん中をずれの許容限と みなすと，それは音響技術者で約 $11^{\circ}$, 非専門家で約 $20^{\circ}$ となる。これらの実験結果から判断すると，20亿 ンチ程度のテレビ受像機 (画角約 $10^{\circ}$ ) では, 音に特別 の注意を払わない限り，通常の 2 チャンネルステレオ でも映像と音像のずれが問題になることはないといえ る。しかし，より大きな画面を近接して試聴する場合 や八イビジョンでは，ずれが気になるお执そがある。

このような視聴賞の性質を考慮すると，ドルビーサ 


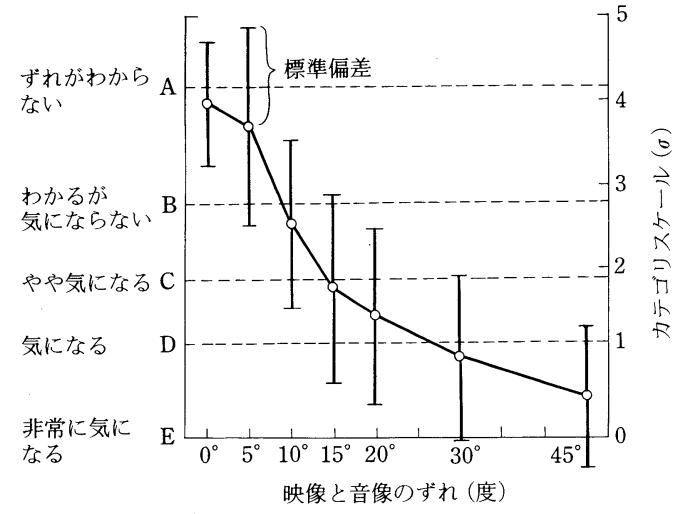

(a) 音響技術者の場合

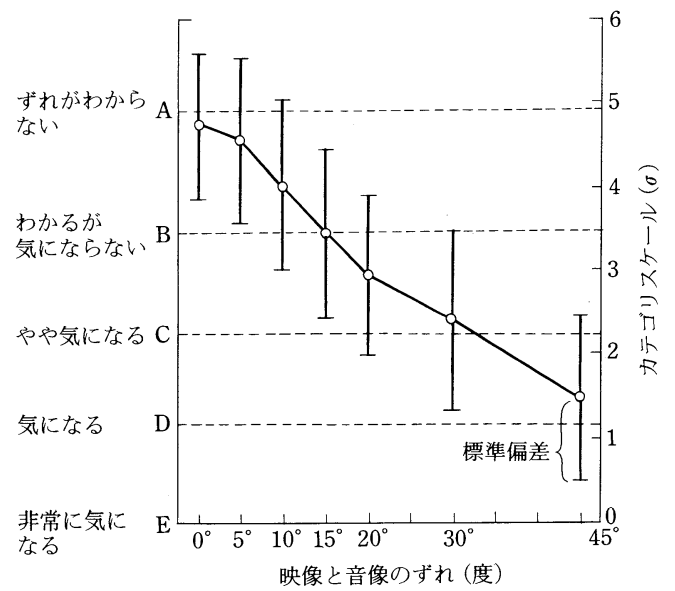

(b) 非尃門家の場合

図 8 映像と音像のずれに対する評価の平均と標準偏差

ラウンドやハイビジョンの音声方式として提案されて いる 3-1 方式 4 チャンネルステレオにおいて, セン夕 一チャンネルを設けられるようになっているのは自然 な方向といえる.テレビの場合, 映画と違ってセンタ ーチャンネルのスピーカを設置しにくいという問題は あるが, 聴取範囲の拡大や左右のスピーカ間隔を広げ
られることによる広がり感の向上など，メリットが大 きいので, 前方の 3 チャンネル化は今後の発展が充分 期待できるであろう.

(1989 年 11 月 9 日受付)

\section{〔参 考 文 献〕}

1) K. Ohgushi, S. Komiyama, K. Kurozumi, A. Morita, J. Ujihara and K. Tsujimoto: "Subjective Evaluation of Multi-Channel Stereophony for HDTV”, IEEE Trans., BC-33, 4, pp. 197-202 (Dec. 1987)

2) 大串: “八イビジョン用 3-1 方式 4 チャンネルステレオ, JAS Journal., 27, 11, pp. 5-12 (1987)

3） NHK 放送技術研究所編：“八イビジョン技術”, 日本放送出 版協会刊, pp. 56-57

4）“研究スポット：音響信号の高能率符号化”, NHK 技研月報, 30, 10 (1987)

5）渡辺, 竹ケ原: “ハイビジョン音声ベースバンド伝送用準瞬 時圧伸 DPCM 方式”, 信学全大, 1384 (1987)

6）星野・竹ケ原：“HDTV 音声 DPCM 伝送氾抢ける最適りー ク係数”信学全大, B460（1988）

7）田辺, 竹ケ原 : “準瞬時圧伸 DPCM 信号の聴感評価”, 音響学 会研究発表会講演論文集, 1-6-16（1987）

8）田辺, 竹ケ原：“準瞬時圧伸 DPCM 信号の距離尺度による評 価”, 音響学会研究発表会講演論文集, 1-3-20（1987）

9) T. Takegahara, H. Tanabe, H. Suganami : "Sound Transmission for HDTV Using Baseband Multiplexing into MUSE Video Signal", IEEE Trans., BC-33, 4, pp. 188 -196 (Dec. 1987)

10）小宮山：“番組音の相関を用いたテープレコーダーとVTR の同期運転”, NHK 技研月報, 27, 3, pp. 80-85（Mar. 1984）

11）小宮山：“大画面テレビ視聴時における音像定位”，音響誌， 43, 9, pp. 664-669 (1987)

12）小宮山：“大画面 TV に扔引る映像と咅像定位のずれの許容 值について”, 信学技報, IE 87-109 (1988)

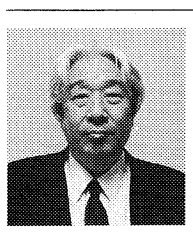

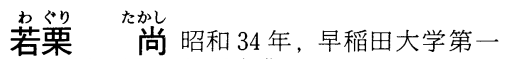
理工学部電気通信科卒業. 同年, NHK に入 局. 静岡放送局技術部を経て, 38 年, 放送 技術研究所音楽研究部に転移, 建築音響, 音 響機器, 音響信号レベル制御, ディジタル音 響技術の研究に従事. 現在, 同放送技術研究 所音響聴賞研究部長.

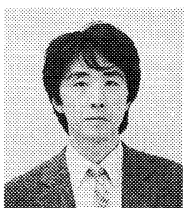

小宮山摄 昭和 52 年, 東京大学大学院 電気工学専攻修士課程修了. 同年, NHK 入局. 静岡放送局を経て, 55 年ょり, 放送 技術研究所に勤務し, 現在に至る. 映像と音 像の相乗効果, 音場の視覚化の研究に従事. 